City University of New York (CUNY)

CUNY Academic Works

\title{
Historical Perspective: The Historical Development of the Society for Occupational Health Psychology
}

Leslie B. Hammer

Portland State University

Irvin Sam Schonfeld

cUNY Graduate Center

\section{How does access to this work benefit you? Let us know!}

More information about this work at: https://academicworks.cuny.edu/gc_pubs/275

Discover additional works at: https://academicworks.cuny.edu

This work is made publicly available by the City University of New York (CUNY).

Contact: AcademicWorks@cuny.edu 


\section{Historical Perspective}

The Historical Development of the Society for Occupational Health Psychology

\section{Leslie B. Hammer}

Past President SOHP, Portland State University

\section{Irvin Sam Schonfeld, Editor, City College of the City University of New York}

The Society for Occupational Health Psychology (SOHP) is the first professional group of its kind in the United States. The development of the Society can be traced to the development of the field of occupational health psychology (OHP). OHP is an interdisciplinary partnership of the psychological and occupational health sciences. The goals of this partnership include the improvement of the quality of people's working lives and the enhancement of the safety, health, and well-being of workers. To our knowledge the first time the term occupational health psychology became visible in the research literature is in 1986 in a book chapter by George Everly, Jr.; the concept of integrating occupational health and psychology, however, has been around much longer (see Julian Barling and Amanda Griffiths's fine history in a chapter in James Campbell Quick and Lois Tetrick's Handbook of Occupational Health Psychology, APA Books).

The professional development of the field in the United States can be traced back to 1990 and efforts by the American Psychological Association (APA; Gwendolyn Keita, Heather Roberts Fox, and others) and the National Institute for Occupational Safety and Health (NIOSH; Steven Sauter, Joseph Hurrell, and others) who jointly organized a series of international conferences on work, stress, and health. Beginning in 1990, the conferences were conducted every two to three years. In addition efforts were made to provide seed money to support the creation of post-doctoral positions in OHP. While two of these were established (one at Duke University and one at Wayne State University), it was soon realized that the only way to train a significant number of graduate students in this field would be to provide support for the development of graduate programs in OHP. Thus, the APA and NIOSH began to support the development of about 3 OHP graduate programs per year beginning in the mid-1990's. By 2001, there were OHP graduate programs in 11 universities across the country. In 1996 the Journal of Occupational Health Psychology under the editorship of James Campbell Quick was founded. The next logical step for this developing field was the organizing of a series smaller meetings that were focused on identifying ways of growing the field of OHP.

Paul Spector and Tammy Allen hosted the first organizational meeting in 2001 at the University of South

Florida in Tampa. Representatives of the 11 graduate training programs in OHP attended. This meeting was followed 18 months later by a meeting of the same group during the much larger March 2003 APA/ NIOSH Work, Stress, and Health conference in Toronto. At the March 2003 meeting formal discussions about creating the Society began. Six months later, in November 2003. Robert Sinclair and Leslie Hammer, with the support of Portland State University, hosted the group in Portland, Oregon. One year later in October 2004, meetings were held at APA headquarters in Washington, DC. The first officers of SOHP were named, and charged with the tasks of putting in place an organizational structure and incorporating the Society. At the Washington meeting, the nascent Society developed a formal relationship with APA. APA agreed to provide a bulk rate for the Journal of Occupational Health Psychology for all Society members, the bulk rate going into effect in 2006. As OHP was developing in the United States through the 1990s, our European counterparts were also busy. Our European colleagues established the European Academy of Occupational Health Psychology (http://www.eaohp.org/) in 1999. With the help of SOHP's founding members, many of whom played roles in the series of meetings that took place between 2001 and 2004, the founders raised funds to support the development of the Society and the establishment of non-profit and tax-exempt status. Once the group of approximately 50 founding members signed on to the Society, SOHP began to enroll as charter members anyone who joined between November 2005 and November 2006. These instrumental founding and charter members are now listed on the Society's website (http://www.sohp-online.org/) and should be recognized as critical supporters of the development of the Society.

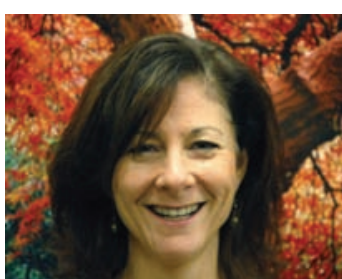

Leslie B. Hammer

Past President SOHP Portland State

University

"...the first time the term occupational health psychology became visible in the research literature is in 1986..." 